\title{
VZGOJA ZA PROŽNO OSEBNOST
}

dr. Bogomir

Novak

Pedagoški inštitut

$v$ Ljubljani

\section{Vpliv dela odraslih na vzgojo otrok}

drasli so že v antiki vzgajali otroke po lastni meri. Vzgoja po meri otroka se je začela v razsvetljenstvu, geslo "vse za otroka " pa se je uveljavilo šele v 20. stoletju. To prepričanje še ni povsem trdno. Tudi danes spoznavamo nove pogoje vzgoje in odkrivamo nekatere njene nove vidike. Ob koncu 20. stoletja smo prišli do spoznanja, da je geslo "vse za otroka " protislovno in da se odrasli, še posebej v današnji adultokratski družbi, ne moremo odreči lastnih vzgojnih meril.

\section{NOVA VLOGA DELA POGOJUJE DRUGAČNO VZGOJO}

V zdajšnjem, prehodnem obdobju je delo neupravičeno postalo manj pomembno področje raziskovanja. In vendar človek še ni prenehal biti delovno bitje (homo faber), hkrati pa tudi ni še postal človek prostega časa. Vzgoja, ki jo zastopamo odrasli kot starši ali učitelji(ce), je še povezana $\mathrm{z}$ delom, ker smo bili v socializmu takšne deležni in je bila izhodišče kot izhodišča za vsako drugo vrsto vzgoje. Danes vemo, da je vzgoja za življenje vseživljenjska in večnamenska. Ni namenjena le delu, ampak tudi kakovostni uporabi prostega časa, v katerem naj bi prevladovala igra. In vendar danes prevladuje $\mathrm{v}$ prostem času pravno nepriznano delo ali siva ekonomija.

Delo $\mathrm{z}$ materijo in vzgoja $\mathrm{z}$ informacijo sta $\mathrm{v}$ nekem smislu že svobodna igra. Ta igra pa pomeni menjavo materialnih dobrin ali izmenjavo enakih človeških lastnosti, npr. ljubezni za ljubezen. $\mathrm{V}$ prvem primeru je osebnost samo maska, $v$ drugem primeru pa gre za izvirno človeško osebnost, ki si lahko prisvoji vse lepo, lepo v umetniškem smislu. Vzgoja lahko teži k umetnosti življenja (lat. ars vivendi), umetnosti ustvarjanja in umetnosti umiranja (lat. ars moriendi). Delo je v najširšem smislu proizvodnja, praksa in ustvarjalnost, v ožjem pa poklic. Vendar dela ni moč obravnavati kot vsemogočno dejavnost, ki bo zadovoljila vse človekove potrebe. Nasprotno, v današnjih proizvodih je čedalje manj živega dela in čedalje več znanja.

Skupna vzgoji, delu in igri je izmenjava - komunikacija. Navajeni smo meriti pozitivne učinke dela, vendar delo nima vedno pozitivnega rezultata. Sizifovo delo je entropično, ker se ponavlja vedno znova od začetka in je tako brez rezultata. Destruktivno delo (npr. ludizem, vojna) pa ima celo negativne posledice.

Tudi vzgoja ni vedno v skladu s svojo intencionalnostjo, ampak je lahko brez učinka ali pa doseže obraten učinek od želenega. Vsaka od teh dejavnosti človeka lahko zasvoji, ker ob njej človek ni le tisti, ki vodi, ampak je tudi tisti, ki je voden - manipuliran. Tako delo, prignano do skrajnosti, človeka vodi $\mathrm{v}$ deloholizem (»karoši« je japonski izraz za bolezen zaradi pretiranega dela), vzgoja v indoktrinacijo, igra pa v izgubo, zaigranost. $\mathrm{Ni}$ človeške lastnosti, ki se ne bi mogla sprevrniti v nečloveško,

Osebnostne lastnosti
postajajo vse bolj
pomembne za
doseganje uspeha $v$
poklicu.
od igrivosti, religioznosti, racionalnosti, iracionalnosti, (permanentne) edukacije, ekonomičnosti, etičnosti do plemenitosti, asociativnosti itd., vendar je možno tudi obratno. Zato je razumljivo, da lahko delo preide vigro.

\section{DELATI DANES POMENI BITI PROŽEN}

Postindustrijska družba potrebuje prožno družino, šolo, podjetje in osebnost. Prožnost (angl. flexibility), dejavna prilagodljivost temelji na večplastnosti človeškega bitja, od telesne, socialne, psihične (zaznave, razum, volja, emocije) do duhovne ravni. Prožna osebnost je najprej problem današnjih odraslih, 
Tragedija pozaposlitvene družbe je, da ji zmanjkuje dela. Nekateri delazmožni kažejo prožno stališče, ko se navajajo na nove, zahtevnejše delovne pogoje, drugi pa se odvajajo od dela in ga ne sprejemajo, četudi se jim ponudi z odpiranjem novih delovnih mest. V nasprotju s predvidevanji, da bo delavce razvoj tehnike osvobodil dela, v razvitem svetu delajo vedno več. Mnogi imajo dela čez glavo, da so z njim že deloholično zasvojeni, drugi pa ga ne morejo dobiti.

ki večinoma izhajamo iz neprožnih družin in prav tako neprožnih industrijskih podjetij.

Konec zaposlitvene družbe in začetek po-zaposlitvene pomeni, da država ne skrbi več za polno zaposlitev vseh delazmožnih. Na takšno stanje rastoče brezposelnosti so delavci premalo pripravljeni, čeprav so bili že doslej prisiljeni, da se sproti prilagajajo gibanju kapitala in potrebam po mobilnosti delovne sile. Hiter razvoj družbenih in tehničnih sprememb terja premeščnje delavcev $\mathrm{z}$ enega delovnega mesta na drugo in opravljanje več poklicev $\mathrm{v}$ življenju. Zaposleni so pod pretnjo brezposelnosti, do- in pre-kvalifikacije. Vseživljenjsko učenje je nujen pogoj za opravljanje poklicnih del, osebnostni razvoj odraslih in sprejemanje vedno novih informacij, ki nastajajo $\mathrm{v}$ mrežni povezanosti sveta. Zlasti odrasli bi se morali bolje usposobiti za učinkovito komunikacijo. Če hoče delavec obdržati delovno mesto, ni več dovolj, da hoče delati, ampak mora ustrezati opisu del in nalog, ki se nanaša tudi na osebne lastnosti, vrsto znanja, sposobnost komuniciranja, sklepanja socialnega partnerstva in funkcionalno pismenost.

Novi cilji dela, ki pa za večino še niso uresničljivi, so samouresničenje, svobodno odloča-

Poklicno delo vpliva na vzgojni slog prek navad in motivov. nje in ustvarjalnost. Za Frankla in Lukasovo (1995) je iskanje oblik sožitja pomembnejše kot iskanje samouresničenja, saj ga vključuje. Globalni, večstranski razvoj je možen tako, da se rast materialne proizvodnje, družbene reprodukcije in osebnosti medsebojno pogojujejo in da se (vsaka) osebnost večplastno razvija glede na senzomotorične, razumske, emocionalne in duhovne sposobnosti. Vedno bolj kompleksni problemi družbe terjajo razvoj »večstranskega mišljenja (Vester, 1992) z obema polovicama možganov. Ne gre več samo za zunanje dejavnike razvoja, ampak tudi za notranje, ki sestavljajo kulturni kapital z znanjem, veščina- mi in sposobnostmi, motivacijo in socializacijskimi obrazci.

Način obnašanja osebnosti je pomemben za opravljanje določenih vrst kvalificiranih, odgovornih del. Nekatera podjetja ga upoštevajo pri sprejemanju prijavljenih kandidatov v službo. Napraviti (prvi) vtis na drugega je postala že prava komunikacijska veščina, ki ne zadeva le zaznavne tipe (npr. koliko lahko vizualec posnema kinestetika), ampak predvsem njihovo samozavest. Razvoj osebnosti zato ni zanimiv le s pedagoškega vidika, ampak tudi z vidika razvoja dela in tehnologije. Za kakovostno poklicno delo danes ne zadošča zunanja disciplina, ampak notranja. Pregovorna slovenska pridnost je še vedno pretežno spodbujana z zunanjimi motivi imetja (avto, denar, lepa hiša), ne pa toliko z notranjimi.

\section{AKCIJA ALI KONTEMPLACIJA}

Nekateri v skladu z novo delovno etiko ne delajo več zaradi objektivne nujnosti, ampak zaradi sebe in svojih najbolj intimnih želja. Po protestantski etiki je treba delati in varčevati za srečo prihodnjih generacij. Danes je obvezno spreminjanje gledišča ali okvira (refraiming pri Robbinsu), tj. gledanja v svetu življenja "sedaj in tukaj ". Če delamo igraje za svoj svobodni, ustvarjalni izraz, postane delo le zavestna aktivnost za samopotrjevanje. Verjamemo, da bomo našli prav tiste, ki iščejo to, kar jim lahko ponudimo. Za pozitivni videz izdelka nas kupci cenijo in spoštujejo. Vprašanje je, ali so ljudje dovolj zreli, da bodo lahko ustvarili pogoje ustvarjalnega dela za večino poklicev. Vzgoja za zrelost (Walters, 1991) to omogoča. Danes po eni strani sprejemamo vedno večjo odgovornost za kakovost, po drugi bi se radi nostalgično umaknili na točko našega prejšnjega razvoja, ko je družba skrbela za nas.

Razlika med industrijskim in informacijskim vrednotnim obrazcem dela in vzgoje je bistvena. Naše vrednote so še ambivalentne. Nihamo med reaktivno, enosmerno in dvosmerno komunikacijo. Ravnati proaktivno in ne več reaktivno pomeni, da se v vsaki situaciji samoiniciativno odločamo za eno izmed možnosti v skladu z opredeljenimi vrednotami. Poklicno delo ne vpliva direktno na vzgojni slog, ampak prek navad, motivov-ciljev in obrazcev vrednotenja. 
Danes ima človek občutek pretirane proizvodnje in potrošnje zaradi pretiranega trošenja energije. Postopek varčnosti nasproti takšni razsipnosti je v osredotočenju - koncentraciji. Stalno usmerjanje pozornosti na en predmet zavesti je prva značilnost kontemplativnega življenja (lat. contemplatio - opazovanje, globoko premišljevanje). Kontemplacija je opazovanje predmeta iz notranje perspektive. Je izvir in poslednji smoter dela/dejavnosti, medtem ko je aktivno življenje poskus obvladovanja zunanje narave. Delovni proces z uporabo orodij je tedaj akcija, pozunanjenje človekovih ustvarjalnih sil, kontemplacija pa njihova ponotranjena stran, to je opazovanje delčka v celoti in s tem zamisel ustvarjalnega akta na podlagi neskončnih možnosti.

Sposobnost koncentracije - osredotočenja je pogoj za učinkovito delo. Pomeni »biti pri sebi in ne le pri zunanjem ovoju ali plasti svoje osebnosti. Biti to, kar si, pomeni delati to, kar delaš. Raztreščen in raztresen človek je povsod in nikjer. Zato govorimo tudi o decentralizirani osebnosti. Ker živi za raznovrstne, pogosto nepovezane vplive zunanjega sveta, ga obvladujejo stvari in ne on njih. Tako je tudi z vzgojo. Starši, ki jih obvladuje potreba po varnosti otroka in mu govorijo »ne smeš tega, ne smeš onega «, ne vzgajajo za življenje, ampak za strah.

\section{TOGA, RAZPUŠČENA ALI PROŽNA DRUŽINA?}

Ni vseeno, $v$ katerem tipu družine bo evropski človek morda našel samega sebe. Razlikujemo med togo, razpuščeno in prožno družino. Prožna družina šele nastaja. Dolgoročno izkazuje primerjalne prednosti pred drugima dvema tipoma, ker goji komplementarne odnose medsebojne pomoči in ne več (a)simetričnih, rivalskih. Danes ne govorimo le o krizi družine in šole, ampak tudi kulture in civi-

Da se vzgoja zaradi odtujenih in neobvladanih pogojev ne bi sprevrgla v svoje nasprotje, je treba razvijati sposobnost pravočasnega razlikovanja pozitivnega od negativnega, sreče in nesreče, vrednega in nevrednega, učinkovitega in neučinkovitega, »gibanje proti drugim ali $\mathrm{k}$ njim (Kren, 1995). lizacije. Totalitarni sistemi so razvoj družine zanemarjali. Zato je nuklearna, okrnjena družina še na razpotju med družbeno in osebnostno, ljubezensko pogojeno družino. Ta oblika se ne bo mogla razviti, dokler prevladuje ločenost ustanov, zlasti družine in šole. Za etiko $\mathrm{v}$ šoli je ključno vprašanje, katera morala/etika v družini prevladuje: patriarhal-

Ni dobra niti prestroga vzgoja niti dopuščanje vsega otroku. Srednja mera je obvladovanje paradoksne intence. Le v prožni družini se otrok razvija većplastno. Otroci lahko postanejo odgovorni, prilagodlijivi, ljubeči in ljubljeni posamezniki, če smo takšni že starši. Po drugi strani otroci starše tudi vzgajajo. Naša vest kot organ smisla nas opozarja, če se ne učimo opravljati funkcije razumevanja, tolažbe, sočutja, ohranjanja materialnega standarda.

na in denarna morala, delovna morala ali etika sožitja. Prav tako je od demokratičnega ali avtokratskega vzgojnega sloga $\mathrm{v}$ družini odvisna potreba in izvedba vzgoje $v$ šoli. Starši (ne)hote sklepajo socialna partnerstva pri vzgoji svojih otrok s šolo in drugimi ustanovami. Danes je vzgojnih subjektov več. Zato so tudi vzgojni vplivi raznorodni, od istosmernih (partnerskih) in raznosmernih do nasprotujočih.

Gibanje k ljudem pomeni gibanje k jeziku sprejemanja, $\mathrm{k}$ poenotenju nasprotujočih delov osebnosti, $\mathrm{k}$ višjim vzgibom, pozitivni samopodobi, brezpogojni ljubezni, k samokontroli negativnih misli, samozaupanju, vživljanju v druge, dejavnemu prilagajanju, sodelovanju, racionalni in emocionalni zrelosti (med statusom quo in radikalno spremembo), dobroti, socialni identifikaciji in skupnim učinkom.

Vzgoja otrok je med od-učenjem starih, avtokratskih vrednotnih obrazcev in prisvajanjem novih, ki naj ne bi dajali občutka, da drug drugemu kratimo svobodni pretok energije, dela in kulturnega kapitala, ampak ga kvečjemu omejujemo. Če je družina zadnje zatočišče sveta brez srca, se zlasti otroci počutijo ne le omejene, ampak tudi prikrajšane. Od-učenje od agresije, ki se poraja iz vrednotne praznine in razosebljenosti, je v vzgoji za notranji mir, notranjo disciplino in sožitje.

Prožnost družine je odvisna od tega, ali imamo njeni člani blokadno konflikten ali razumevajoč in spravljiv način reševanja problemov. Otroci lahko pridobijo sposobnost reševanja problemov, če jim zaupamo in jih spoš- 


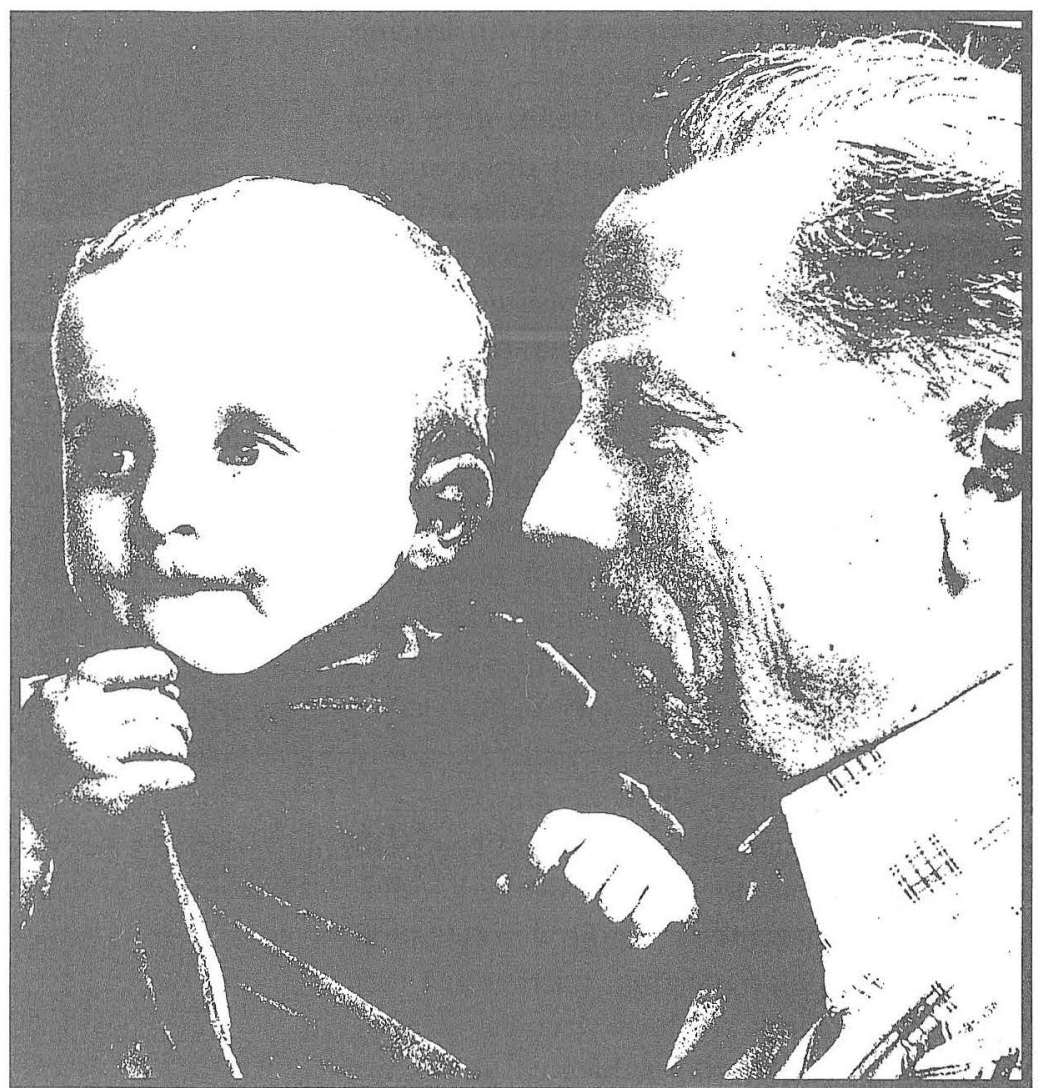

tujemo. Odločajo se otroci sami, odrasli jih smemo le usmerjati in se ne smemo odločati v njihovem imenu. Že družina bi morala dati otrokom vzgojo srca in razuma, razvoj kontrolnih mehanizmov, občutek odgovornosti in spoštovanja. Starši, ki izhajamo iz trdih družin, težko najdemo pravo mero. Ostanemo trdi ali pa postanemo v svojih družinah premehki. Zanimivo je, da govorimo o prijazni šoli, o prijazni ali prijetni družini pa ne.

\section{Če želimo, da bodo otroci uspešno reševali probleme, jim moramo zaupati.}

Vzgoja, ki obsega vse plasti osebnosti, vključuje tudi pozitivne emocije in mišljenje.

Kadar člani družine drug drugemu prisluhnejo, so cilj in ne sredstvo, kar pomeni uveljavljanje igre zmagam - zmagaš. Otroku starši pokažemo, kako s celovito analizo sprejmejo odgovornost za napake, da je drugič ne bi ponovili. Radi prelagamo odgovornosti na drugega, kar pa ne omogoča duhovnega napredka. Colorosova (Coloroso, 1996) izhaja iz načela, da starši $z$ otroki ne bi smeli ravnati na način, ki ga ne bi želeli skusiti na lastni koži. To etično načelo drugačnosti v enakosti velja $\mathrm{v}$ vseh svetovnih verstvih. V njem utemeljuje prožni vzgojni slog, ki ni niti zgolj permisiven niti represiven. Družina je toliko bolj zdrava, kolikor bolje družinski člani usklajujejo svoje funkcije med seboj.

\section{SPORAZUMEVANJE IN AVTONOMNOST OSEBNOSTI V DRUŽINI}

Umetnost medsebojnega komuniciranja, sporazumevanja se kot umetnost razumevanja protislovij dogaja najprej v družini. "Vse za otroka « si otrok razlaga v smislu koristi staršev in ne njegove. Premalo in preveč ljubeči starši niso dobri. Trstenjak je ironično zapisal, da imamo že za vsako stroko in delo izdelane delovne profile, oddelke na šolah, le za poklic staršev še nimamo delovnega profila (1994: 111). Vzgoja je stvar obeh staršev. Vendar so tudi zaradi občutka pomanjkanja kompetenc in odsotnosti očetov danes pogoste enostarševske družine.

Ključna za razumevanje oblikovanja osebnostne avtonomije je avtoriteta. Avtoriteta je odvisna zveza, na katero določena osebnost pristaja, dokler ne postane neodvisna. Zato se otroci podrejajo interesom odraslih $\mathrm{v}$ vzgojnem procesu. $\mathrm{V}$ procesu oblikovanja osebnosti je avtoriteta neizogibna. Vsak individuum je sposoben osamosvojitve, ker je po naravi samoregulativno bitje. Žal pa nekateri ne dosežejo optimalno možne stopnje avtonomije, kar ostane njihov osebnostni in družinski in družbeni problem. Avtonomija je $\mathrm{v}$ procesu samospoznanja in samokontrole posameznika v njegovi težnji po razvoju. Od načina delovanja sistema spodbud in sankcij je odvisno, koliko družinski člani eden drugemu pustijo dozoreti $\mathrm{v}$ emocionalnem, razumskem, socialnem in duhovnem smislu. Verjetno je, da, čim več storijo za neodvisnost starši, tem več lahko storijo otroci, ker (ne)hote vzgajajo z enakim za enako.

Molčeči, javno neangažirani mladini devetdesetih let manjka samospoštovanja. Ker sebe ne spoštuje, tudi odraslih ne spoštuje in obratno. Nespoštovanje mladih je že posledica nespoštljivosti odraslih $v$ začaranem krogu, kar je videti kot družbeno maščevanje - nemeza v posttotalitarnem obdobju. Mladina, ki izhaja iz družin z laissez-faire vzgojo in je plod protislovnega gesla »vse za otroka», je brez moralnih norm in $\mathrm{z}$ otopelo vestjo.

Za premostitev slabosti družinske vzgoje se danes v svetu najpogosteje uporablja transak- 
cijska analiza. Njen namen je, da odrasli jaz stalno išče ravnotežje med sanjskim otroškim jazom, ki hoče takojšnjo zadovoljitev potreb, in starševskim kritičnim jazom (Berne (1994). $\mathrm{Na}$ ta način pride do drugačnega samovrednotenja starševskih vzgojnih vplivov, ki jih občutimo kot vrednotne meje. Za starševsko vzgojo je pomembno zdravljenje prizadetosti otroškega jaza odraslih, kljub temu da ostajamo ranljivi vse življenje.

\section{ČLOVEKOV OSEBNI RAZVOJ}

Pojem osebnosti je proizvod novoveške zgodovine. Nastal je kot zanikanje starih neposrednih odnosov z naravo in družbo in kot potrditev delovno posred(ova)nih. Prva socialna maternica za razvoj osebnosti je družina, druga šola, tretja podjetje. Za sodobni menedžment je razvoj osebnosti pomemben po neizčrpnosti človeških virov in možnosti njihovega vedno boljšega upravljanja.

$\mathrm{Za}$ (post)moderno osebnost so značilne te lastnosti: (1) pripravljenost sprejemati nove izkušnje, ideje in vzorce obnašanja, (2) sposobnost samostojnega oblikovanja stališč do različnih vprašanj, (3) pozitivno vrednotenje različnih stališč, (4) sorazmerno visoka stopnja informiranosti, (5) naravnanost na sc danjost in prihodnost in ne več (toliko) na preteklost, (6) sposobnost dolgoročnega načrtovanja javnih zadev in zasebnega življenja, (7) prepričanje o predvidljivosti tega sveta pa tudi zanesljivosti obljub in dolžnosti ljudi in institucij, (8) vrednotenje tehničnega znanja in spretnosti, izobraževanja in poklicne aspiracije, (9) spoštovanje dostojanstva in osebnosti drugih ljudi (Inkeless, Smith, 1974).

Vse te dinamske lastnosti moderne osebnosti izhajajo iz predpostavke, da je svet načelno racionalno obvladljiv. Opredeljene so tako, da vključujejo tudi informacijske in komunikacijske sposobnosti v pozitivnem in negativnem smislu. Industrijska družba je proizvajala trdo, jekleno, skopo osebnost. Za avtoritarno osebnost kot plod totalitarnih sistemov je značilna poudarjena hierarhičnost, ekskluzivistični način mišljenja, nezaupanje vase, $\mathrm{v}$ druge in $\mathrm{v}$ demokratične ustanove, zaprtost vase, nevroticizem, opiranje na vodjo in na nacionalistične obrazce ter ksenofobija.

Takšna osebnost je rezultanta psihosocialnih in ekonomsko-materialnih vplivov, dejavni- kov in izkušenj, ki so pridobljene $\mathrm{v}$ okviru družinskega, vzgojno-izobraževalnega, organizacijskega in širšega socialnega okolja. Ciljev tega razvoja je več: samorealizacija oz. samoaktualizacija, samoizpopolnitev, samopreseganje itd. na osnovi samodejavnosti, samorefleksije, samoizpopolnjevanja in sodelovanja $z$ drugimi. Navsezadnje ugotovimo, da se ti cilji ujemajo s postmodernimi vrednota$\mathrm{mi}$ in da niso zgolj osebni, ampak tudi social$\mathrm{ni}$, ker se procesa personalizacije in socializacije tesno prepletata.

Etična dolžnost posameznika je, da uskladi svoje sposobnosti (4), vrednote in sredstva med seboj. Posameznik ne spreminja sebe le $\mathrm{z}$ delovanjem na naravo izven sebe, ampak še bolj z delom na sebi, ki ima različne oblike, kot so meditacija, samovzgoja, molitev, avtohipnoza, relaksacija in joga. To pomeni, da jih mora na določen samodiscipliniran način opredmetiti vsaj z držo ali gibi, da jih lahko ozavesti. Danes prevladuje stališče, da se posameznik spremeni šele takrat, ko sprejme sebe (tudi svoje negativne lastnosti) $\mathrm{v}$ celoti. To pomeni, da osebnostni razvoj ni istoveten $\mathrm{z}$ razvojem poklicne kariere, lahko je pa z njo povezan. Osebnostna ambivalenca se kaže zlasti pri vplivih od zunaj, ki jih lahko določen posameznik razume kot kratenje osebnih pravic ali kot pomembno spodbudo. Vemo, da je moč osebnosti od posameznika do posameznika tako zelo različna, da zato razlikujemo med odvisnimi in samostojnimi osebnostmi. Danes se razvijajo spodbude krepitve in žal s povečevanjem števila odvisnosti (npr. bele droge) tudi slabitve moči osebnosti, kar je pomembno za vrednotenje vzgoje. Cilji, ki si jih postavljamo, nas motivirajo za ustvarjalnost in sprožijo $\mathrm{v}$ nas ustvarjalne sposobnosti. Zato je tako pogubno samopodcenjevanje. $\mathrm{V}$ svetu tekmovalnosti, kjer je posameznik v stalni dilemi med potrebnostjo in odvečnostjo, zamenljivostjo in enkratnostjo, odvisnostjo in samostojnostjo, ne bi smeli izgubiti osebne vizije, ker z njo izgubimo kompas.

\section{ČLOVEK POTREBUIE TUDI DRŽAVNI RED ZA SVOJ RAZVOJ}

Človek ni le svobodno bitje, ampak tudi odtujeno bitje, kar se že od antike dalje ponazarja 
$\mathrm{z}$ odnosom med svetlobo in temo. Zato mu ne zadošča le notranja varnost brez državnega reda. Država je kot »objektivni duh « kontrolni dejavnik z vzgojnimi in izobraževalnimi posledicami, ne glede na to, ali jih priznamo ali ne. Zato ni le šola ideološki aparat države, ampak je tudi država formalno sistemski okvir vzgoje in izobrazbe $\mathrm{v}$ šoli in družini. Glede na politični sistem presojamo odnos med avtentičnim in neavtentičnim - maskiranim načinom življenja posameznikov. V socializmu je nosil posameznik poleg politične še druge maske, ki so bile z njo povezane. Politika je namreč urejala/regulirala vsa področja življenja. Tako je posameznikom preprečila samostojno izkazovanje. Maske potrebuje posameznik na tistih področjih udejstvovanja, na katerih ne najde avtentičnih odgovorov,

Z osebnostnim razvojem razumemo biopsihosocialni razvoj oz. razvoj raznovrstnih sposobnosti posameznila. Osebnostni razvoj je razvoj osebnostnih lastnosti posameznika v smislu vrednot, nagnjenj, motivov, stališè in interesov, sposobnosti, znanja in delovnili dosezkov. prožnih odzivov na določene vplive, ki jih doživlja kot tuje pritiske. Če se tega zaveda, skuša t. i. » kognitivno disonanco « preseči znotraj istega ali znotraj drugačnega vrednotnega sistema s transformacijo - predelavo. Različne maske nastanejo zaradi osebnih blokad razvoja nekaterih sposobnosti.

Eksistenčna kriza je za tiste, ki je ne obvladajo, usodna frustracija. O ekonomski maski govorimo šele $\mathrm{v}$ novem veku, ker prej ni bilo ekonomskega motiva. V socializmu je obstajalo skrito delovanje zakona vrednosti, ki poraja ekonomsko masko npr. v obliki zasebnega in osebnega prisvajanja državne/družbene lastnine. Pokazalo se je, da je bilo v socializmu prikrivanje realnega stanja družbenih razmer še večje kot v kapitalizmu. Nikjer niso bili in niso družbeni odnosi povsem razvidni. Vendar je določena stopnja transparentnosti pogoj presojanja javnih in privatnih zadev. To je tudi pogoj razvoja demokracije. To pomeni, da lahko govorimo o demaskiranju kot odstranjevanju mask, kot o deblokadah, dezideologizacijah, demistifikacijah in deregulacijah le do določene meje. To ne pomeni popolnoma odprte osebnosti, ki ne bi bila v odnosu do nečesa izven sebe in $\mathrm{v}$ sebi tudi zaprta. Osebnost na višji kulturni ravni bo laže trans- formirala negativne zunanje vplive $\mathrm{v}$ notranje pozitivne kot osebnost $\mathrm{z}$ nižjo kulturo. Zato ni nujno, da si osebnost nadene masko takrat, ko obstaja družbeni pritisk, je pa zelo verjetno. Tudi v totalitarnih režimih obstajajo elementi občečloveške morale in primeri vzornih, zrelih osebnosti, ki so proti takšnemu režimu.

\section{POSTMODERNA KULTURA}

Znaki postmoderne kulture so v težnji po kakovosti življenja, ekološki občutljivosti, udejstvovanju pri razvoju demokracije, samoizražanju ter ohranjanju lokalnosti in tradicionalnih običajev. Posamezniki bi se radi osvobodili totalitarne kontrole sistema s tehnikami samonadzora. Toda to je že Rousseaujev paradoks vzgoje, ki ga je ohranil tudi Foucault s prisilnimi zvezami. Gre za posrečeno iskanje tretje možnosti med nadzorom drugih in samonadzorom, med subjektom in objektom vzgoje kot tudi med dovoljenjem in preprečevanjem. Kot dopolnilo materialne proizvodnje nastopa informacija in $\mathrm{z}$ njo samoizraznost, ki postavlja v prvi plan kulturo. Gre tudi za reorganizacijo in obogatitev manualnega dela $\mathrm{v}$ avtonomni skupini. Uvaja se delo na daljavo (teledelo) in nastaja fleksibilni delovni čas. Težnja personalizacije usmerja posameznika $\mathrm{k}$ temu, da vedno bolj skuša spontano izraziti to, kar je in kar čuti. To ustvarja potrebo po celoviti zdravstveni vzgoji s preventivnim preprečevanjem negativnih posledic šole in dela. Pri tem je pomembno, da začenjajo prevladovati individualne vrednote: avtentičnost osebnosti, izpovedi, intimnost in solidarnost z živim svetom. Posameznik mora nenehno presojati ustreznost svojih stališč, vrednot, odnosov do dela in življenja ter nadomeščati zastarele z novimi. Osamosvaja se od družine, socialnega izvora, kulture in razredne pripadnosti: odloča o izobrazbi, pokli$\mathrm{cu}$, delovnem mestu, načinu življenja in zakonskem partnerju. Odvisen pa je od trga delovne sile, stopnje izobraževanja, potrošnje, družbenih norm, mode, prometa, psiholoških in medicinskih nasvetov. Govorimo lahko o novih oblikah neodvisnosti in odvisnosti posameznikov, ki pomenijo tudi njihove nove razvojne meje. Vprašanje je, kako doseči hkratno odgovornost posameznika za skupnost in skupnosti zanj. 
V evropski zgodovini je splošno poudarjen skladen razvoj sposobnosti, vendar so v vsakem obdobju izpostavljene druge specialne sposobnosti. Za zastopnike kontrolne teorije (Boffey, 1995) so te vrednote svoboda, veselje (zabava), ljubezen in moč. Seveda se da vsako od teh vrednot razumeti $\mathrm{v}$ dvojnem pomenu. Pozitivna svoboda že vključuje negativno, vendar je tudi sama racionalno omejena. $\mathrm{Za}$ stopniki kontrolne teorije predpostavljajo notranjo disciplino, h kateri spada sprejemanje odgovornosti za svoja dejanja. Posebno pomembno za starše, vzgojitelje in učitelje je prepričati gojence in učence, da sprejmejo odgovornst za svoje delo v šoli, ne da bi jih obsojali za njihovo neodgovornost. Bluestein (1997) na primerih učiteljev in učencev opisuje, kako je mogoče izvajati takšen postindustrijski sistem »zmagam - zmagaš « nasproti industrijskemu »zmagam - izgubim «. Pri tem pokaže, da spoštovanje lastne osebnosti in osebnosti drugega presega moje in tvoje misli in dejanja, kar je že iztočnica za preventivno preprečevanje in reševanje (ne)potrebnih konfliktov.

V postindustrijski oz. informacijski družbi že potekajo drugačni procesi brisanja - dediferenciranja človekove razdvojenosti, ki je nastala $\mathrm{z}$ industrijsko revolucijo. Zato tudi Bloom (1997) opozarja, da nima smisla postavljati razuma (sposobnost razločevanja) proti duhu modrosti. Treba je speljati vrednoto notranjega miru tudi v zunanji svet do političnega miru. Agresivnost je posledica strahu. Pot $\mathrm{k}$ neustrašnosti najdemo že $\mathrm{v}$ Bibliji, pri Krišnamurtiju, Powllu, Hribarju.

Postmoderna dopušča združevanje novejšega, razumskega znanja z najbolj arhetipičnim, intuitivnim. Duh deluje po principu stopnišča. Preblisk odkrijemo, ko odhajamo zdoma ali spat. Iz tega izkustva izhaja metoda sestopanja in pripravljanje, ki je videti kot odlaganje (inkubacijska faza ustvarjalnosti).

Danes je človek samega sebe pripeljal tako

Enostransko poveličevanje telesnega ali duhovnega brez emocionalnega vodi do čustvene podhranjenosti. Odtod izhajajo regresivne tendence vračanja na primitivne, barbarske obrazce infantilnega vedenja, brezbrižnosti, napadalnosti in zločinskosti v sodobnem človeku. daleč, da je zaradi vrednotnega izpraznjenja postal izsrediščen (ekscentričen) tudi sam. Še več: zaradi zapostavljanja kontemplacije je slejkoprej konec tudi dela. Antropološki smisel kontemplativnega stila življenja je v iskanju ravnotežja $\mathrm{z}$ aktivnim stilom življenja, kar je navsezadnje tudi sožitje svetega in posvetnega. Oba sta sicer epohalno razločljiva, vendar v skrajni posledici nista razdvojljiva. Kontemplacija kot askeza ni bila nikoli meniška moda, ampak kvečjemu manira. Danes postaja nuja preživetja $v$ sožitju med prevladujočo instrumentalizirano tehnično kulturo in duhovno kulturo. Prva je že kar preveč razvita $v$ primerjavi $z$ drugo, ki je glede na predindustrijska obdobja premalo razvita. Tehnike so postale razpoznavni znak celo za kulturo mišljenja in meditiranja. Kdor ne izvaja teh tehnik, ne obvladuje procesa. Tehnike so v učbenikih mišljenja (npr. De Bono) in meditiranja tudi navedene. Verjetno $\mathrm{v}$ zgodovini še nikoli ni bilo toliko zbranih metod in tehnik za samoizgrajevanje, samopremagovanje in samoaktualizacijo kot danes.

Človek se je danes znašel v duSožitje tehnične in
duhovne kulture je
pogoj za preživetje. hovnem supermarketu, ker trpi zaradi prevelike ponudbe duhovnih poti, o katerih se našim staršem še sanjalo ni. Vsi valovi svetovnih duhovnih kultur pljuskajo tudi $\mathrm{k}$ nam. Nimamo kompasa orientacije, dokler se nismo naučili poslušati svojega notranjega glasu. Med prvimi, ki so se tega zavedeli, je Bloom (1997).

Danes stopa namesto pasivnega, neozaveščenega potrošnika celovito izobražen, informiran, aktiven, "zeleni « potrošnik, ki izraža zaskrbljenost zaradi onesnaževanja (notranjega) okolja pri proizvajalcih in vpliva na boljšo kakovost proizvodov/storitev.

\section{DOZOREVANJE OSEBNOSTI JE VSEŽIVLJENJSKII PROCES}

Pot osebnega dozorevanja traja od rojstva do smrti. Za uspeh v duhovnem življenju je treba upoštevati: (1) notranji klic - težnjo, (2) askezo, očiščevanje in osmišljanje trpljenja, (3) vztrajnost in stanovitnost, (4) širjenje zavedanja.

Pot duhovnega napredka je mogoče razložiti tudi po Sheldrakejevih (Sheldrake, 1981) 
morfičnih poljih, kjer se živi organizmi sami uravnavajo. Ko individuum uvede nov način obnašanja, to za trenutek spremeni morfogenetsko polje. Če se obnašanje dovolj pogosto ponavlja, se tvorna resonanca poveča in začne vplivati na celotno vrsto. Čim več ljudi obogati nivo lastne zavesti, bolj bo okrepljeno morfogenetsko polje višjih stanj zavesti in olajšan drugim ljudem dostop do teh stanj. Po eni strani gre za prenos obnašanja na velike razdalje, po drugi za resonance duha - duše in telesa znotraj osebnosti. Zaradi povratnega vpliva vibracij na našo fiziološko pogojenost ni vseeno, v kaj verjamemo in kako. Pragmatistična usmerjenost (7) predpostavlja dolgoročno, tako kot bližina do sebe distanciranje, ki naj ne bi bilo cinično ali celo nihilistično.

\section{SKLEP}

Prožna osebnost je tista, ki transformira hkrati kulturno okolje in sebe. Postmoderna osebnost je hkrati kontemplativna in aktivna, obrnjena navznoter k zamišljanju ustvarjalnega akta in navzven $\mathrm{k}$ realizaciji $\mathrm{v}$ proizvodu. Prožna osebnost je nasproti odvisni osebnosti z masko avtonomna, zrela, zdrava, uravnotežena, stabilna in interaktivno prilagodljiva na spremembe. Razvoj prožne osebnosti je zaradi vedno hitrejših sprememb življenjska nuja in naloga. Vpliv poklicnega dela odraslih na vzgojo otrok je tudi sam pogojen s prejšnjo (ne)prožno družino in (ne)prožnim podjetjem oz. ustanovo, kjer so zaposleni. Prožni vzgojni slog ni niti represiven kot v preteklosti, niti zgolj permisiven, ki daje vse na otroka, ampak je srednja pot med obema. Slog vzgojiteljev je odvisen od njihovega odnosa do življenja (igra, samovzgoja) in ne le od dela. Danes je prožnost način kakovostnega obvladovanja družbenih in osebnih sprememb.

\section{LITERATURA}

Benson, Herbert (1996): Timeless Healing. The Power and Biology of Belief. London, Simon Schuster.

Berne, Eric (1994): Games people play. London, Penguin Books.

Bloom, William (1997): Prvi koraki na duhovni poti. Ljubljana, Iskanja.

Bluestein, Jane (1997): Disciplina 21. stoletja. Kako učence navajamo na samonadzor in prevzemanje odgovornosti? Ljubljana, Zavod Republike Slovenije za šolstvo.
Boffey Barnes (1995): Umetnost samoprenove. Kako s kontrolno teorijo postaneš človek, kakršen bi rad bil? Radovljica, Regionalni izobraževalni center.

Coloroso (1996): Otroci so tega vredni. Notranja disciplina, največ kar lahko podarimo svojemu otroku. Ljubljana, Tangram.

De Beauport, Elaine (1996): The three faces of mind: developing your mental, behavioral and intelligences. New York, Plenum.

De Mello, Anthony (1990): Ptičja pesem. Zrna modrosti iz svetovnih verstev. Ljubljana, Župnijski urad.

Frankl, Viktor (1994): Volja do smisla. Celje, Mohorjeva družba.

Glasser, William (1994): Dobra šola. Vodenje učencev brez prisile. Radovljica, Regionalni izobraževalni center.

Glasser, W. (1994): Učitelj v dobri šoli. Radovljica, Regionalni izobraževalni center.

Enkelmann, Nikolaus (1997): Moč retorike. Prepričati z govorom, glasom in osebnostjo. Kranj, Vernar Consulting.

Inkeless, A., Smith, D. H. (1974): Becoming Modern. Cambridge, Harward University Press.

Huth Almuth, Huth Werner (1992): Meditacija. Stik z lastno notranjostjo. Ljubljana, CZ.

Kren Obran, Tilka (1995): Vrednote mladih med ideali kulture in resnico dejanj. Radovljica, Didakta.

Mackay, Harwey (1993): Plavati z morskimi psi in ostati živ. Kako premagati konkurenco $\mathrm{v}$ prodaji, vodenju, motivaciji in pogajanju? Ljubljana, Gospodarski Vestnik.

Marcuse, Ludvig (1959): Amerikanishes Philosophieren. Pragmatisti ten Polytheisten Tragiker. Hamburg, Rowohlt.

Musek, Janek (1993): Osebnost pod drobnogledom. Maribor, Obzorja.

Musek, Janek (1995): Ljubezen, družina, vrednote. Ljubljana, EDUCY.

O'Connor Joseph, Seymour John (1996): Spretnosti sporazumevanja in vplivanja. Uvod v nevrolingvistično programiranje. Žalec, Sledi.

Ramovš, Jože (1995): Družina. Zbornik predavanj na osrednjih strokovnih prireditvah v Sloveniji v letu družine. Ljubljana, Institut Antona Trstenjaka.

Robertson, Douglas L. (1988): Self-Directed Growth. Muncie. Accelerated Development.

Robbins, Anthony (1995): Grenzenlose Energie. Das Power Prinzip. Wie Sie ihre persoenlichen Schwaechen in positive Energie verwandeln. Das NLP Handbuch fuer jedermann. Muenchen, W. Heym Verlag.

Sheldrake, Rupert (1981): A New Science of Life: Hypothesis of Formative Causation. New York, Blond and Biggs, London and State Mutual Books.

Shinn Florence Scovel: Igra življenja in kako jo igrati. Velenje, Tone Žove.

Trstenjak, Anton (1994): O družini. Ljubljana, Institut Antona Trstenjaka.

Vester, Frederic (1992): Kriza prenaseljenih območij. Ljubljana, DZS.

Walters, Donald (1991): Vzgoja za življenje. Celje, Mohorjeva družba. 